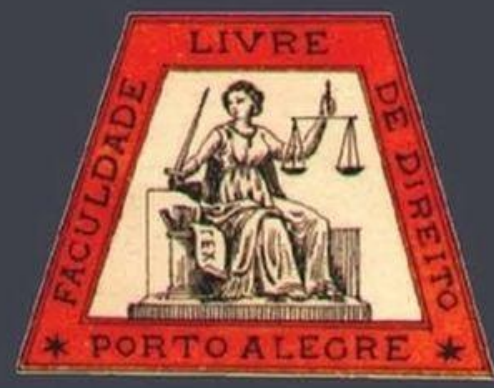

As vertentes do Jusnaturalismo e a atualidade temática do Direito Natural

The strands of jusnaturalism and the current usage of the Natural Law

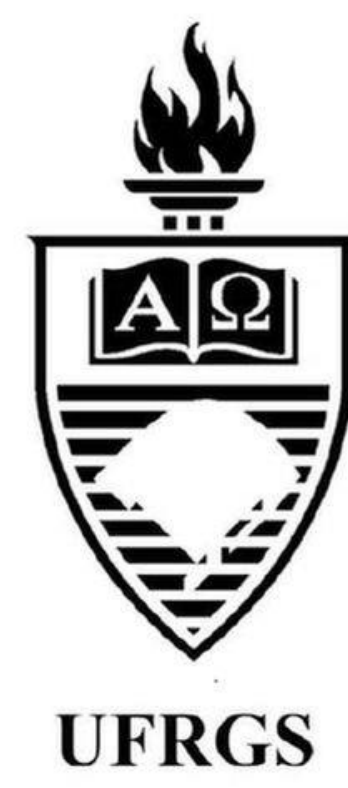




\title{
As vertentes do Jusnaturalismo e a atualidade temática do Direito Natural
}

\author{
The strands of Jusnaturalism and the current usage of the Natural Law
}

Reis Friede*

\section{REFERÊNCIA}

FRIEDE, Reis. As vertentes do Jusnaturalismo e a atualidade temática do Direito Natural. Revista da Faculdade de Direito da UFRGS, Porto Alegre, n. 40, p. 44-60, ago. 2019.

\section{RESUMO}

O debate que envolve o Jusnaturalismo e o Juspositivismo tem inspirado as reflexões de juristas e filósofos. Muito embora se possa afirmar que grande parte das históricas controvérsias associadas ao confronto entre o Direito Positivo e o Direito Natural já tenham sido superadas, subsistem inúmeros aspectos que merecem uma dedicação acadêmica. Não obstante opiniões divergentes, as quais pugnam pelo enfraquecimento teórico do assunto, o passar dos séculos demonstra justamente o contrário, posto não ter conseguido eliminar a estima dos pensadores pela temática ora desenvolvida. Deste modo, o presente artigo discorre sobre as diversas vertentes históricas (Cosmológica, Teológica e Racional) do Jusnaturalismo, analisando, ainda, a atualidade temática do Direito Natural.

\section{PALAVRAS-CHAVE}

Teoria do Direito. Direito Natural. Jusnaturalismo. Legal theory. Natural Law. Jusnaturalism. Juspositivism. Juspositivismo.

\begin{abstract}
The debate regarding Jusnaturalism and Juspositivism has been inspiring the reflections of jurists and philosophers for a long time. Although it may be affirmed that a great deal of the historical controversies associated to the confrontation between the Positive Law and Natural Law has already been overcome, there are numerous aspects which deserve an academic dedication. Notwithstanding divergent opinions, which struggle for the theoretical weakening of the subject, the passing of the centuries demonstrates precisely the opposite, given that it could not eliminate the esteem of the thinkers for the subject in discussion. Therefore, the current work analyses the characteristics of the various historical strands of Jusnaturalism (Cosmological, Theological and Rational), as well as the current usage of the Natural Law.
\end{abstract}

\section{KEYWORDS}

\section{SUMÁRIO}

1. A vertente cosmológica do Jusnaturalismo. 2. A vertente teológica do Jusnaturalismo. 3. A vertente racional do Jusnaturalismo. 4. A atualidade temática do Direito Natural. Conclusão. Referências.

\footnotetext{
* Reis Friede é Desembargador Federal. Mestre e Doutor em Direito e Professor e Pesquisador do Programa de Mestrado em Desenvolvimento Local do Centro Universitário Augusto Motta (UNISUAM). Correio eletrônico: reisfriede@hotmail.com. É autor do livro “Teoria do Direito”.
} 


\section{A VERTENTE COSMOLÓGICA DO JUSNATURALISMO}

A doutrina aponta uma série de concepções que surgiram ao longo do tempo com o fim de justificar a existência de direitos naturais. Bittar, situando o presente assunto na história do pensamento jusfilosófico, apresenta a seguinte sinopse, desde a Grécia Antiga à Idade Moderna:

A discussão do tema não é uma inovação nos meandros teóricos do Direito. Pode-se mesmo dizer que a sede dessas discussões já se encontra entre os pensadores gregos, sobretudo a partir dos sofistas e de Sócrates (séc. V a.C.), que haviam detectado a origem da discussão na oposição entre nómos $e$ phýsis, oposição que somente tomou proporções cada vez mais significativas na literatura filosófica após o advento de Platão e Aristóteles (séc. IV a.C.). Por sua vez, os romanos sediavam a discussão na oposição entre ius gentium e ius civile (séc. II a.C. a II d.C.), sendo que os medievais (Santo Agostinho, Abelardo, São Tomás de Aquino) somente trouxeram diferenciais religiosos para esses conhecidos conceitos por meio da ideia da existência da lex divina (séc. V a XII d.C.) [...]. Com Grotius (séc. XVII d.C.), com seus contemporâneos e com a tradição posterior (Maquiavel, Jean Bodin, Hugo Grócio, Thomas Hobbes, Jean-Jacques Rousseau, John Locke, Spinoza, Pufendorf), o racionalismo moderno universaliza a razão humana e encontra os fundamentos para a discussão do tema secularizando a noção de direitos fundamentais eternos, naturais e imutáveis, cuja primeira consagração se deu com a Declaração dos Direitos do Homem e do Cidadão (1789). Desde esse período, a questão passa a se tornar ingrediente indispensável de toda a busca jusfilosófica, não deixando mais de se encontrar nos manuais de filosofia do direito como página indispensável de reflexão.
(BITTAR, 2001, p. 183-184).

De acordo com Bittar (2001, p. 184), independentemente de sua longevidade histórica, o debate a respeito da "noção de Direito Natural deve reavivar o que há de nuclear em sua definição, ou seja, a ideia de natureza", aduzindo o autor que a perda da semântica do termo natureza, incorporado que foi no bojo da expressão Direito Natural, provocou a "erosão do valor que se agrega e que se carrega no mesmo". Ao discorrer sobre tal problema de ordem semântica, e resumindo as diversas concepções jusnaturalistas forjadas ao longo dos tempos, Bittar assinala que "os direitos, conforme o entendimento e a significação da palavra natureza, decorreriam ou da própria constituição do mundo natural [...], ou da natureza racional do homem [...], ou da natureza sociopolítica humana [...]", dando margem ao surgimento de diversos modelos de Jusnaturalismo (BITTAR, 2001, p. 185), a serem abordados em seguida.

Quanto ao primeiro fundamento do Direito Natural - a própria constituição do mundo natural -, explica Bittar (2001, p. 185) que, de acordo com tal concepção jusnaturalista, o mundo natural, com as suas características próprias, imprime condições para a vida em geral (inclusive para a vida humana), as quais formam um "conjunto de dados que determinam a própria existência do homem", fixando, desta feita, um "conjunto de diretrizes para o seu comportamento". Por conseguinte, ainda segundo o mesmo autor, "leis inderrogáveis e comuns a todos e a tudo [...] ditam as condições da própria existência no mundo físico, condicionando a própria formação do direito e das normas jurídicas" (BITTAR, 2001, p. 185). Refere-se Bittar, especificamente, à denominada concepção cosmológica do Direito Natural, abordagem que concebe a essência deste na própria natureza das coisas.

Desse modo, na Antiguidade Clássica, o 
denominado Jusnaturalismo Cosmológico fundava-se na ideia de que os direitos naturais refletiriam as leis (eternas e imutáveis) reitoras do próprio funcionamento do Cosmos. Admitiase, desta feita, a existência de "uma justiça natural, emanada da ordem cósmica, marcando a indissociabilidade entre natureza, justiça e Direito" (SOARES, 2013, p. 134).

Conforme ilustrado por Montoro (2011, p. 305), uma das manifestações dessa vertente pode ser encontrada no teatro grego, mais precisamente em Antígona, famosa tragédia helênica na qual Sófocles (497-406 a.C.), um dos tragediógrafos mais relevantes do período clássico (juntamente com Ésquilo e Eurípedes), narra que o Rei Creonte (herdeiro do trono Tebas) teria proibido o funeral de Polinice (irmão de Antígona), por ter o falecido tomado em armas contra Tebas. De acordo com o espetáculo teatral em comento, Antígona, no entanto, desrespeita a ordem real e sepulta Polinice, invocando, para tanto, que acima da lei emanada do rei haveria leis eternas. Antígona, ao ser questionada por Creonte a respeito do motivo pelo qual havia descumprido o edito proibitivo do sepultamento de Polinice - invocando, para tanto, a existência de leis divinas -, responde categoricamente:

Mas Zeus não foi o arauto delas para mim, nem essas leis são as ditadas entre os homens pela Justiça, companheira de morada dos deuses infernais; e não me pareceu que tuas determinações [refere-se à lei do Rei Creonte] tivessem força para impor aos mortais até a obrigação de transgredir normas divinas, não escritas, inevitáveis; não é de hoje, não é de ontem, é desde os tempos mais remotos que elas vigem, sem que ninguém possa dizer quando surgiram. E não seria por temer homem algum, nem o mais arrogante, que me arriscaria a ser punida pelos deuses por violá-las. (Fragmento de Antígona, citado por MARCONDES e STRUCHINER, 2015, p. 18).
Malgrado o trecho acima transcrito não se revestir dos atributos próprios de um texto de cunho jurídico, político ou filosófico, Antígona, enquanto tragédia helênica representava à época muito mais do que um simples espetáculo teatral; refletia, em última análise, o próprio modo de ser daquela sociedade.

Dissertando a respeito da importância da cultura grega para o tema em exame, Reale (2002, p. 312) assevera que a ideia de um Direito Natural, distinto do Direito Positivo, é deveras antiga, sendo constatada nas "manifestações mais remotas da civilização ocidental a respeito do problema da lei e da justiça, o mesmo ocorrendo na cultura do Oriente"; no entanto, prossegue o professor Reale, é justamente entre os "pensadores gregos que a aceitação de um Direito Natural, como expressão de exigências éticas e racionais, superiores às do Direito positivo ou histórico, passa a ser objeto de estudos especiais, até se converter em verdadeira teoria" (REALE, 2002, p. 312).

Sócrates defendia que o justo era a obediência incondicional às leis da pólis. Ele afirmava que um cidadão de bem deveria obedecer também às leis más, para não encorajar o cidadão perverso a violar as boas, o que desagradava profundamente os Sofistas, que afirmavam que o bem, para os homens livres, era o mal para os escravos. Como se sabe, a opulência de Atenas no século $\mathrm{V}$ a.C. (o chamado século de Péricles, quando floresceram a filosofia, a arte e o que viria a ser a ciência) foi conseguida por uma força de trabalho composta basicamente por escravos.

Em A República, de Platão, a ideia do bem surge ligada estreitamente à noção de justiça. Para Aristóteles, a ideia ou forma do bem não supõe univocidade, pois não existe uma única forma do bem para todos e para tudo. Já para os Sofistas, o bem (e o seu duplo, o mal) era uma questão de ponto de vista, pois cada homem tem um modo próprio de ver e de conhecer as 
coisas, do que resultava a tese de que não poderia existir uma verdadeira ideia de bem, ou uma ciência objetiva e universalmente válida.

Ainda no âmbito de uma perspectiva jusnaturalista na Antiguidade Clássica, recorda Montoro (2011, p. 306) que Aristóteles, opondose às reflexões de Arquelau, segundo o qual "o direito não existiria por natureza, mas somente em virtude de lei", afirmou que "o bem e o justo, objetos de que trata a ciência política, dão lugar a opiniões de tal forma divergentes e às vezes de tal forma degradadas, que se chegou até a sustentar que o justo e o bem existem apenas em virtude de lei e não têm nenhum fundamento na natureza".

No que se refere ao Direito Natural em Roma, Marco Túlio Cícero (106-43 a.C.) é frequentemente recordado como aquele que promoveu a síntese entre a filosofia grega e a cultura romana. Além de possibilitar a divulgação da filosofia helênica, Cícero opera uma profunda fundamentação da concepção de Direito, com base no pensamento grego (SOARES, 2010, p. 147). Especificamente no que concerne ao Direito Natural em Roma, Cícero faz "apologia à lei natural", ou seja, aquela "que não precisa ser promulgada pelo legislador para ter validade". Ao contrário, é justamente a lei natural que "confere legitimidade ética aos preceitos da lei positiva, como ratio summa insita in natura; non scripta, sed nata lex; vera lex, recta ratio, naturae congruens" (REALE, 2002, p. 313).

Assim, ao iniciar uma abordagem a respeito do Jusnaturalismo em Roma, o primeiro personagem a ser rememorado passa necessariamente por Cícero, considerado um dos grandes representantes do pensamento político, filosófico e jurídico de Roma, cuja obra sofreu influências das filosofias que o antecederam, tais como a Sofística, o Socratismo, o Platonismo, o Aristotelismo e o Epicurismo (BITTAR e ALMEIDA, 2011, p. 173).
Em Roma, os mestres da jurisprudência ensinavam que, além do direito próprio de cada Estado, existe um direito decorrente da natureza humana (MONTORO, 2011, p. 306-307). Em De Legibus (Sobre as Leis), Cícero afirma que a lei não pode simplesmente originar-se dos homens, que seriam demasiadamente frágeis e limitados para tanto, razão pela qual "ela viria de um poder superior, no qual os homens, que compartilham algo desse poder, através de sua racionalidade, se baseiam para daí derivar suas leis, que devem consistir na promoção do bem e na proibição do mal e em sua punição quando este decorrer da fraqueza humana" (MARCONDES e STRUCHINER, 2015, p. 34).

Reale, ao analisar alguns fragmentos fundamentais do Direito Romano, entre os quais a obra de Cícero, verifica que "a distinção já posta na Grécia entre o Direito Positivo e o Direito Natural, ou melhor, entre o justo por natureza e o justo por lei ou convenção" é novamente observada em Roma:

Existem mesmo na obra de Cícero passagens de invulgar beleza, nas quais se tece a apologia da lex como expressão da ratio naturalis, sempre igual por toda parte, sempiterna, que determina o que deve ser feito e o que deve ser evitado. Bem poucas vezes a consciência da lei natural como momento essencial da Ética atingiu tamanha beleza e precisão como na obra ciceroniana. (REALE, 2002, p. 628).

Sintetizando o Jusnaturalismo em Roma, mormente em Cícero, Bittar e Almeida lecionam que é precisamente na ordenação cósmico natural que se pode encontrar o fundamento de toda ética e de todo conceito de justiça na teoria ciceroniana, sendo as leis naturais, em tal contexto analítico, "a ordenação do todo", de modo que o "direito natural passa a representar a única razão de ordenação da conduta humana na República" (BITTAR e ALMEIDA, 2011, p. 187). 


\section{A VERTENTE TEOLÓGICA DO JUSNATURALISMO}

A dimensão teológica é a marca que caracteriza o Jusnaturalismo na quadra medieval, através da qual se estabelece a fundamentação divina dos direitos naturais. Em tal momento histórico, a teoria jusnaturalista apresentava conteúdo teológico, pois os fundamentos do Direito Natural eram a inteligência e a vontade divinas, devido ao fato de a sociedade estarem marcadas pela vigência de um credo religioso e pelo predomínio da fé (DINIZ, 2000, p. 36). Assim, diversamente do que ocorrera no pensamento grego, o Direito Natural, no bojo da Idade Média, passa a encontrar fundamento na origem divina, vale dizer, na vontade de Deus, vertente que restou conhecida como Jusnaturalismo Teológico.

Argumentam Bittar e Almeida que, tendo em vista a difusão da filosofia e a expansão de seus postulados na história do pensamento, é possível afirmar que "a maior contribuição para a formação do pensamento medieval não foi romana, mas grega", sendo lícito concluir, ademais, que foi justamente da "síntese e da conciliação dos postulados religiosos com os postulados gregos que se iniciaram diversas correntes do pensamento no Medievo" (BITTAR e ALMEIDA, 2011, p. 208).

Com efeito, no que se refere ao Jusnaturalismo Medieval, cabe destacar, de início, a influência advinda de Santo Agostinho (354-430), Bispo de Hipona, cujos pensamentos filosófico e teológico influenciaram sobremaneira a cultura ocidental, configurando uma autêntica sinopse entre a filosofia grega (mormente a de Platão) e o Cristianismo, representando, outrossim, "uma síntese positiva entre religião e filosofia", dado que se constata, principalmente, em Confissões, A Trindade, A Cidade de Deus e $O$ Livre Arbítrio, principais obras agostinianas (CASTILHO, 2017, p. 63). Com efeito, a doutrina cristã dominará a história da cultura cristã na Idade Média.

Quanto aos temas que permearam as cogitações de Agostinho, Marcondes e Struchiner aludem que o "problema da natureza humana e do caráter inato da virtude, a origem do Mal, o conceito de felicidade, a liberdade e a possibilidade de agir de forma ética" conformam, em síntese, as principais questões éticas - herdadas da filosofia grega e pensadas a partir dos ensinamentos do Cristianismo - que receberam as reflexões do Bispo de Hipona (MARCONDES e STRUCHINER, 2007, p. 50).

Ademais, a leitura da obra de Santo Agostinho permite extrair preciosos elementos para a exegese da relação entre Estado e Igreja, dos fundamentos do Direito Natural e do Direito Positivo e da questão pertinente à legitimidade dos governantes (WOLKMER, 2001). Retratando tal relação, e discorrendo sobre as particularidades do Direito Natural sob a ótica agostiniana, Morrison (2012, p. 72-73) afirma que, para Agostinho, o Direito Natural é a "porção intelectual do homem na verdade de Deus, ou na lei eterna de Deus". Interpretada como a razão e a vontade do Deus cristão, a "lei eterna tornou-se a divina razão, a vontade de Deus que controla a observância da ordem natural das coisas". Assim, a lei eterna é a razão de Deus no comando da regularidade, sendo a apreensão intelectual humana dos princípios eternos do chamado Direito Natural (MORRISON, 2012, p. 72-73). Cunha (2002, p. 61), por sua vez, explica que, para Agostinho, a noção de lei eterna configura um princípio da sabedoria, "implícita à própria perfeição divina e, portanto, sempre justa", ordenando, pois, todas as coisas.

Com efeito, para Santo Agostinho, as leis criadas pelos homens - vale dizer, as lei temporais -, para serem consideradas justas, "devem estar de acordo com o princípio do 
Direito Natural, que, por sua vez, deriva do direito eterno" (MORRISON, 2012, p. 73). Conforme se observa, Agostinho cogita de uma lei temporal (lei terrena, estabelecida pelos homens) $e$ de uma lei eterna. De fato, Agostinho não refuta a relevância da aludida lei terrena para a convivência humana. Entretanto, para ele, tal lei não basta. É preciso uma outra (a lei eterna), cuja existência independe de fatores temporais. Em suma, Agostinho postula por uma lei (a lei eterna) que possa funcionar como parâmetro para a lei terrena (a lei temporal), sendo certo que esta última, para ser considerada justa e legítima, precisa estar alicerçada naquela.

Agostinho acreditava que a "realidade da justiça de Deus devia ser encontrada na estrutura da natureza humana em sua relação com Deus"; diante de tal perspectiva, a justiça, portanto, não era uma resultante da opinião pessoal do homem, mas, sim, "alguma coisa inculcada por um certo poder inato”, padrão este que, uma vez adotado, "significava impor pesadas limitações morais ao poder político" (MORRISON, 2012, p. 73).

No que concerne particularmente à concepção de justiça, Morrison (2012, p. 73) relata que, para Agostinho, a "relação fundamental na justiça não é aquela que se dá entre homem e homem, mas, sim, entre o homem e Deus", de modo que a "justiça coletiva é impossível sem a justiça individual da relação com Deus", pois "se essa justiça não for encontrada em um homem, tão pouco poderemos encontrar em uma multidão". Fica evidente, pois, que Santo Agostinho elevou a Igreja e a religião a um patamar de superioridade em relação ao próprio Estado, considerado pelo culto pensador de Hipona como um "produto da condição pecaminosa do homem", razão pela qual deve haver um "órgão de controle"; não obstante, Santo Agostinho "não admite que o princípio da força seja superior ao princípio do amor (MORRISON, 2012, p. 73).
Para Santo Agostinho, a justiça humana é aquela que se realiza inter omnes, tendo como fonte a lei humana, responsável por comandar o comportamento do homem em relação aos outros homens e com o que o cerca. Por seu turno, a justiça divina é aquela que a tudo governa, e que se baseia na lei divina (caracterizada por ser absoluta, imutável, perfeita, infalível e infinitamente boa e justa), que é aquela exercida sem condições temporais para sua execução, não se sujeitando ao relativismo sociocultural que marca as diferenças legislativas entre os povos, civilizações e culturas diversas.

Desta feita, se "a lei humana se encontra desenraizada de sua origem, seu destino só pode ser o erro e o mau governo das coisas humanas"; ao contrário, se "a lei humana se aproxima da fonte de inspiração que está a governar o coração humano (lei divina), então as instituições humanas passam a representar um avanço em direção do que é absolutamente verdadeiro, bom, imperecível e eterno" (BITTAR e ALMEIDA, 2011, p. 214). Tal raciocínio dicotômico a respeito do tema justiça, segundo alguns autores, revela nitidamente a influência que o dualismo platônico (lei eterna - lei temporal; lei divina lei humana; corpo - alma; terreno - divino; mutável - imutável; perfeito - imperfeito; relativo - absoluto, etc.) exerceu sobre a filosofia agostiniana (BITTAR e ALMEIDA, 2011, p. 215).

No século XIII, cerca de oito séculos depois, o pensamento político de Santo Agostinho encontra consolidação em São Tomás de Aquino (1225-1274), cujas obras repercutiram enormemente nos campos da Teologia e da Filosofia. De acordo com as lições de Reale, o Direito Natural, consoante o disposto na doutrina de Tomás de Aquino, "repete, no plano da experiência social, a mesma exigência de ordem racional que Deus estabelece no universo, o qual não é um caos, mas um cosmos" absolutamente dotado de ordem; ainda em tal perspectiva, a lei 
positiva ("estabelecida pela autoridade humana competente") deve se subordinar à lei natural ("que independe do legislador terreno e se impõe a ele como um conjunto de imperativos éticos indeclináveis"), havendo, pois, "duas ordens de leis, uma dotada de validade em si e por si (a do Direito Natural) e outra de validade subordinada e contingente (a do Direito Positivo)" (REALE, 2002, p. 314).

Tomás de Aquino é rememorado como um pensador que, acolhendo e adotando como ponto de partida a ética aristotélica, sistematizou e viabilizou a leitura dos escritos de Aristóteles, razão pela qual frequentemente se afirma que "a influência recebida do aristotelismo dota as lições tomistas de clarividência particular, pois, ainda que os textos de aquinatense se imiscuam no tratamento de temas metafísicos, teológicos, políticos, sociais, tudo é racionalmente concebido, concatenado, logicamente explicado, metodicamente exposto", sistematização facilmente perceptível na Suma Teológica (escrita entre 1266 e 1274), a mais conhecida de suas obras (BITTAR e ALMEIDA, 2011, p. 247).

Tomás de Aquino entendia que "o Ser Supremo, além de Criador, é também o Legislador de todo o Cosmos por ele criado, o qual governa segundo sua lei eterna", sendo que o Estado e o poder político, na ótica de Aquino, "decorrem da agência criadora de Deus". Ademais, prossegue Aquino, Deus "criou os homens para viverem em sociedade, pois só a vida em sociedade é uma vida plena ou feliz, digna da condição do homem na escala das criaturas", razão pela qual "é necessário haver um governo terrestre, que regule a multidão, levando-a a alcançar o bem coletivo" (MACIEL, 2013, p. 17-18). Com efeito, a síntese entre Estado, Igreja, Direito Positivo e Direito Natural em São Tomás de Aquino é assim retratada por Adeodato: "o direito divino por essência, a lex aeterna, permanece intangível para o mundo", sendo que "o direito divino por participação, a lex naturalis, é a fonte inspiradora do que hoje se chamaria direito positivo, e a lex humana, por intermédio dos eflúvios que este capta daquele" (ADEODATO, 2012, p. 157).

Conforme se observa, Tomás de Aquino concebe algumas espécies de lei: a) a lei eterna (lex aeterna), $b$ ) a lei natural (lex naturalis) e $c$ ) a lei humana (lei puramente convencional e relativa, e que deve procurar refletir o conteúdo das leis eterna e natural). Assim, a ordem universal é dada pela lei eterna, que não está sujeita às atribulações a que as leis humanas estão. A lei natural, por sua vez, representa a participação racional na lei eterna. A lei humana é produto de convenção, só adquirindo força a partir de sua instituição, devendo representar a concretização da lei natural; significa dizer que a lei humana (a lei positiva) deve retratar aquilo que a lei natural prescreve. Por conseguinte, cumpre ao legislador positivar o que é dado pela natureza. Com efeito, nessa linha de raciocínio, a positivação daquilo que se afigura contrário à lei natural implica em um direito injusto e ilegítimo. De qualquer modo, convém registrar, o "fato de uma lei positiva não estar de acordo com a lei natural não justifica a desobediência ao que foi criado pelo homem; a desobediência só se justifica, para Tomás de Aquino, quando houver um entrechoque entre a lei humana e a lei eterna" (BITTAR e ALMEIDA, 2011, p. 255257).

São Tomás de Aquino, na Suma Teológica, define justiça como sendo a "vontade constante e duradoura de dar a cada um o que lhe é devido", sendo o devido "aquilo que é ordenado para cada um, de acordo com as tendências individuais naturais, tendo por objetivo a perfeição de seus fins", postulado do qual se extraem, no mínimo, duas conclusões: $a$ ) o "devido a cada um não é conferido pelo Direito Positivo, mas, sim, pelas tendências naturais da natureza humana", e $b$ ) o Direito Positivo que 
violar o que é naturalmente devido ao homem poderá ser considerado injusto com base no Direito Natural. Observamos, neste particular quanto ao conceito de justiça, uma aproximação entre as filosofias aristotélica e tomista, posto que, consoante adverte Morrison (2012, p. 79), parte do impulso para essa teoria do Direito Natural já havia sido desenvolvida por Aristóteles (em Ética a Nicômaco), mormente quando o filosófico grego assinala a distinção entre justiça natural (physikon dikaion, caracterizada por ser imutável) e justiça convencional (nomikon dikaion, qualificada por ser mutável).

\section{A VERTENTE RACIONAL DO JUSNATURALISMO}

O denominado Jusnaturalismo Moderno (ou Racional) passa a conceber o Direito não mais a partir de fundamentos espirituais ou divinos. Bittar (2008, p. 2) recorda que "o racionalismo moderno universaliza a razão humana, secularizando a noção de direitos fundamentais eternos, naturais e imutáveis, cuja consagração se deu com as Declarações do século XVIII, em especial com a Declaração de Direitos de Virgínia (1776) e a Declaração dos Direitos do Homem e do Cidadão (1789)".

Tal fase, segundo Nader (2010, p. 174), será caracterizada por quatro marcas fundamentais: o reconhecimento de que a natureza humana seria fonte do Direito Natural, a admissão da existência remota do estado de natureza, o contrato social como origem da sociedade e a existência de direitos naturais inatos. Soares $(2013$, p. 144) ilustra que, "quando o homem do Renascimento produziu uma inversão antropocêntrica na compreensão do mundo, vendo-o a partir de si mesmo" e, por conseguinte, "não mais a partir de Deus, o tratamento do problema da justiça sofreu uma marcante inflexão", sendo o Jusnaturalismo
Teológico, então, gradativamente substituído por uma concepção Jusnaturalista Racional, movimento que se utilizou da ideia de "uma razão humana universal para afirmar direitos naturais ou inatos, titularizados por todo e qualquer indivíduo, cuja observância obrigatória poderia ser imposta até mesmo ao Estado, sob pena do direito positivo corporificar a injustiça".

A propósito, Pinheiro e Souza (2016, p. 67) apontam uma retrospectiva histórica muito bem sintetizada a respeito da relação entre os Direitos Positivo e Natural ao longo das Idades Média e Moderna, explicando que "até o início da Idade Moderna é difícil identificar uma oposição mutuamente excludente entre o Direito Positivo e o Direito Natural". Ainda segundo eles, "a tradição aristotélico-tomista consolidada sustentava uma relação de coordenação entre as duas leis" [positiva e natural], inferindo, pois, que até o final da Idade Média "é possível identificar a importância do Direito Positivo, que, no entanto, não pode negar a lei natural". Entretanto, no início da Modernidade, observa-se uma iniciativa de "dissociar o Direito Natural do Direito Positivo", sendo a tradição da lei natural "abandonada e relegada a um elemento histórico, sem força sobre o conceito moderno de Direito" (PINHEIRO e SOUZA, 2016, p. 67), o que nos permite refletir, em seguida, a respeito da atualidade temática do Direito Natural.

\section{A ATUALIDADE TEMÁtica DO DIREITO NATURAL}

Como visto nos itens anteriores, a questão que envolve os denominados Jusnaturalismo e Juspositivismo (e seus respectivos contrastes teóricos) tem inspirado, ao longo do tempo, as reflexões de juristas e filósofos. Assim, não obstante a frequente afirmação segundo a qual o debate acerca do Direito Natural teria perdido a consistência própria dos grandes temas, mormente diante da 
forte influência exercida pela tradição positivista, forçoso reconhecer que o assunto em questão ainda desperta muitas investigações, estando mesmo longe de ser considerado ultrapassado.

Diferentemente do que apregoa a corrente positivista, há, a nosso ver, uma atualidade temática do Direito Natural. Em contraposição ao pensamento atualmente hegemônico, acreditamos que uma incursão na teoria do Direito Natural nada tem de ultrapassado. Pelo contrário, o simples fato de que muitos autores contemporâneos dedicaram (e ainda dedicam) anos de suas reflexões acadêmicas a respeito do supostamente "envelhecido" Direito Natural por si só revela que a perspectiva positivista, em sua radical (e, porque não dizer, infundada) oposição ao Direito Natural, ainda não encontrou respostas para muitas inquietações que insistem em atormentar o Direito.

Nesse sentido, impossível não aludir, por exemplo, a Leo Strauss (1899-1973), cujo intuito de revigorar o Direito Natural é demonstrado em uma de suas principais obras (Droit Naturel et Histoire), reconhecidamente um clássico da Filosofia (em especial, da Filosofia Política) do século passado. O título da obra (Direito Natural e História) parece mesmo refletir a essência da preocupação de Strauss: trazer novamente o Direito Natural para o centro do debate filosófico, uma vez que o desprezo com o qual tem sido tratado impede que o assunto seja conhecido na sua essência.

Strauss discorda frontalmente da afirmação categórica, própria do Positivismo Jurídico - e seu correspondente "culto moderno à ciência", consoante expressão de Michel Villey, empregada em Questões de Tomás de Aquino Sobre Direito e Política, obra editada no Brasil pela Martins Fontes, 2014, p. 132 -, segundo a qual todo o Direito decorreria de arbítrio humano, sendo, pois, fruto da vontade do homem. Ele sustenta, ao contrário, que o Direito
Natural é superior e fundador do próprio Direito Positivo. E aponta duas razões que, na sua ótica, conduziram à atual oposição ao Direito Natural. Para Strauss, uma delas seria a necessidade de se resguardar o valor da segurança jurídica, em particular no que se refere ao primado da obediência à lei posta pelo Estado. A segunda teria relação com o Relativismo. Assim, conforme Villey, "os positivistas voltam ao ataque, alegando as descobertas da ciência contemporânea, ou seja, o velho argumento da diversidade dos direitos" (2014, p. 147).

$\mathrm{Na}$ citada obra, e particularmente no que interessa ao texto ora desenvolvido, Strauss formula objeções ao Positivismo. Para ele, refutar a doutrina do Direito Natural significa, em última análise, defender que todo o Direito ostenta um viés meramente positivo. Vale dizer, que o Direito constitui obra exclusiva dos Legisladores e dos Tribunais (STRAUSS, 2009, p. 4). Em apertada síntese, Strauss tece críticas, dentre outros, à Escola Histórica - doutrina que alude ao denominado Volksgeist ("espírito do povo") -, segundo a qual o Direito seria fruto de uma dada cultura ou de uma determinada época, sendo, portanto, mutável. Strauss adverte que da constatação de que há múltiplas concepções de Direito não se pode extrair uma conclusão destinada a inadmitir o Direito Natural (STRAUSS, 2009, p. 14).

Ao refutar o mesmo argumento relativista, especificamente o defendido por Hans Kelsen (1881-1973), um dos maiores expoentes do Positivismo Jurídico, Michel Villey (19141988), francês, filósofo do Direito, professor honorário da Universidade Paris II, reconhecidamente um dos mais renomados especialistas nas obras de Aristóteles e São Tomás de Aquino, explica que o professor de Viena "caiu no contrassenso de confundir direito natural e lei natural", termos (direito e lei) que, segundo explicação de Villey (2014, p. 147), não são sinonimicamente empregados em Tomás de 
Aquino (Suma Teológica).

Tomás de Aquino distingue entre grupos de "primeiros princípios" incluídos na lei natural (sendo o primeiro o de buscar o bem e fugir do mal), cujo valor é imutável, e as consequências que variam. [...]. Bem diferente é o estatuto do direito natural [...], porque o direito é relação entre pessoas e coisas, mudando com as situações em que pessoas e coisas se vejam implicadas. O direito natural é multiforme. (VILLEY, 2014, p. 147-148).

E segue Villey (2014, p. 148) dizendo que o próprio Aristóteles já afirmara que "uma coisa é o direito natural 'entre nós' [referindo-se aos gregos], e outra na Pérsia”. Em tom retrospectivo, Villey (2014, p. 135) explica que “a voga do 'direito natural' atingira o ápice na época do Iluminismo", sendo que, no século XIX, surge aquilo que o professor francês criticamente denominou de "fobia" ao Direito Natural (Naturrechtsphobie). E continua Villey, em tom metafórico, mas extremamente esclarecedor quanto ao rumo que o Positivismo pretendeu conferir ao Direito Natural: "Quando, segundo a visão comtiana da história da Razão humana, foi realizada a transição para o positivismo, o Direito natural foi tachado de metafísico", sendo, então, proclamada sua "morte"; "o engraçado, porém, é que se continua a atacar seu cadáver" (VILLEY, 2014, p. 135). Entretanto, paradoxalmente: "Os Kelsen, os Bobbios, os Hart e outras sumidades atuais da filosofia do direito dedicam obras enormes à demolição de uma filosofia do direito considerada desaparecida" (VILLEY, 2014, p. 135), dado este que comprova quão atual é o tema sob exame, ou seja, que a questão do Direito Natural não está resolvida. Aliás, "falta muito para isso" (VILLEY, 2014, p. 151).

Irresignado com o referido "abandono" (consoante as palavras de Pinheiro e Souza) ou com a mencionada "sentença de morte" (conforme a metáfora de Villey), o australiano
John Mitchell Finnis (1940-), atualmente professor emérito de Oxford, integrante da $\mathrm{New}$ School of Natural Law, postula uma releitura do pensamento de São Tomás de Aquino - a quem Finnis atribui uma importância ímpar na presente temática -, mormente com o escopo de viabilizar uma espécie de revigoramento do Direito Natural.

Leandro Cordioli, ao apresentar a obra Direito Natural em Tomás de Aquino: sua Reinserção no Contexto do Juspositivismo Analítico - texto produzido por Finnis, e publicado no Brasil em 2007 -, recorda a formação deste autor no seio da tradição da Jurisprudência Analítica. Tal origem explica perfeitamente vários momentos do pensamento de Finnis, notadamente quando este diz que "um teórico não pode fornecer uma descrição teórica e uma análise dos fatos sociais, ao menos que também participe do processo de avaliar, de entender o que é realmente bom para as pessoas humanas e o que é realmente requerido pela razoabilidade prática" (FINNIS, 2007b, p. 17).

$\mathrm{O}$ último trecho destacado entre aspas também revela quão inseparável são, para Finnis, os aspectos descritivo e avaliativo na metodologia de uma Ciência Social - tal como a Ciência do Direito -, permitindo, assim, que se estabeleça um liame entre os processos de descrição (pertinente aos positivistas) e de avaliação (concernente aos jusnaturalistas) do Direito. Some-se a isso a influência que São Tomás exerceu sobre a carreira de Finnis. Por conseguinte, é possível dizer que a obra acadêmica do professor australiano apresenta e conjuga muitos aspectos de ambas as vertentes analítica e aquiniana.

Com efeito, um tal debate a respeito da atualidade do tema ora examinado também demanda uma incursão mínima nas reflexões de Finnis, notadamente as consubstanciadas na obra Lei Natural e Direitos Naturais (Natural Law and Natural Rights, 1980), texto publicado no 
Brasil em 2007, por intermédio da Unisinos -, na qual o autor formula uma teoria destinada a legitimar o Direito Natural a partir de critérios razoáveis de justificação (FINNIS, 2007b), culminando por se destacar como o pensador expoente daquilo que se convencionou chamar de Neojusnaturalismo, termo este adotado para sinalizar o "ressurgimento" experimentado pelo Direito Natural a partir da década de 1980.

Em Lei Natural e Direitos Naturais, Finnis toma como ponto de partida a denominada Lei de Hume, exposta por David Hume (1711-1776) no Tratado da Natureza Humana (Treatise of Human Nature). Como se sabe, não apenas Hans Kelsen, "best-seller das faculdades de direito e campeão do positivismo" - frase ironicamente empregada por Michel Villey, 2014, p. 135 -, mas também vários outros positivistas (Jeremy Bentham e H. L. A. Hart, por exemplo), adotaram a ideia contida na Lei de Hume - cuja síntese defende a impossibilidade de se derivar de um ser um dever - como um dos argumentos para atacar frontalmente as teorias do Direito Natural, as quais, segundo afirmam os críticos, extrairiam o que deve ser realizado daquilo que a natureza é. Nesse sentido, colhe-se de Michel Villey a seguinte referência crítica a Kelsen e à Lei de Hume: Kelsen argumenta a partir da "lei" (atribuída a Hume) de que, a partir daquilo que "é" (na natureza), a lógica veda concluir o que deve ser. Em francês: do indicativo não se pode deduzir o imperativo (Henri Poincaré).

Mas ele [Kelsen] prefere falar alemão, e sua doutrina é inspirada na filosofia Kantiana. Do Sein - escreve ele -, ou seja, do Ser, assunto da Razão teórica, não se pode extrair um Sollen, "normas" que prescrevam um Dever-Fazer. (VILLEY, 2014, p. 136).

Finnis (2007b) conclui que, por conta de tal incompreensão, o Direito Natural, ademais de ser rejeitado, restou caricaturalmente apresentado pela crítica positivista. Em contraposição, Finnis pondera que a teoria de Direito Natural em São Tomás de Aquino não se encontra fundada em aspectos empíricos da natureza humana. Refutando a aludida crítica, ele anota que a "afirmação repetida de Tomás de Aquino de que os primeiros princípios da razão prática são indedutíveis refuta a acusação ou a suposição comum de que sua ética tenta invalidamente deduzir ou inferir dever do ser" (FINNIS, 2007a, p. 35).

Segundo o professor de Oxford, São Tomás amparou-se naquilo que ele mesmo designou de princípios da razão prática, caracterizados por serem autoevidentes e não dedutíveis (FINNIS, 2007a, p. 35), tendo em vista que, para apreendê-los, basta que se empregue a razão. O primeiro deles, a propósito, restou consubstanciado na frase "o bem deve ser perseguido e feito e o mal, evitado" (FINNIS, 2007a, p. 34).

Finnis, então, conclui que o que é bom ou mal não decorre de qualquer manifestação empírica, mas, sim, de tais princípios. Ele adverte, ainda, que "ao descrever os primeiros princípios como autoevidentes”, Tomás de Aquino quer dizer que "a autoevidência é relativa", ou seja, aquilo que "não é óbvio para alguns será autoevidente para aqueles que têm uma experiência mais ampla e uma compreensão melhor dos outros aspectos da questão" (FINNIS, 2007a, p. 35).

Em termos conceituais, e conforme explicam Pinheiro e Souza (2016, p. 71), a expressão razoabilidade prática, para Finnis, "significa decidir, assumir compromissos, eleger projetos e executá-los, em uma palavra, 'agir', e não apenas 'fazer"' (PINHEIRO e SOUZA, 2016, p. 71). Do mesmo modo, Adrian Sgarbi, também discorrendo sobre FINNIS (substancialmente a partir de Lei Natural $e$ Direitos Naturais), esclarece que a razoabilidade prática cumpre uma dupla função: ademais de configurar um bem humano, ela constitui "um 
processo de raciocínio que possibilita distinguir o pensamento prático correto do pensamento prático incorreto", o que permite, em última análise, "avaliar os atos humanos que são razoáveis dos atos que não são razoáveis" (SGARBI, 2007, p. 672).

$\mathrm{Na}$ mesma sequência de ideias, importa ainda referir ao pensamento de Luis Fernando Barzotto, da Universidade Federal do Rio Grande do Sul, o qual, adotando a argumentação exposta por Tomás de Aquino na Suma Teológica, explica que a "teoria da lei natural é uma teoria da razão prática", sendo ela capaz de definir "os termos e o funcionamento da racionalidade humana no que diz respeito à ação", cujo primeiro princípio da razão prática é: "o bem é para ser praticado e procurado; o mal é para ser evitado" (BARZOTTO, 2010, p. 74).

O professor da UFRGS reconhece em John M. Finnis o "mérito de ter mostrado que os deveres naturais de justiça, em Tomás, derivam de um dever de amizade que pode ser expresso na regra de outro", cuja essência prescreve: "faze ao outro o que queres que o outro faça a ti, ou trata-o como um outro eu, isto é, trata-o como amigo" (BARZOTTO, 2010, p. 153). Assim, considerando que "o princípio central da lei natural nas ações intersubjetivas é a dita regra de ouro, a lei humana positiva passa a ser vista como tendo a finalidade de estabelecer uma relação de amizade, podendo ser definida como aliança, antes que medida ou ordem" (BARZOTTO, 2010, p. 154).

Revelando o modo como jusnaturalistas e juspositivistas geralmente se posicionam quanto ao debate em questão, interessante registrar que, para Finnis, "os estudiosos do direito que apresentam ou compreendem suas teorias como 'positivistas', ou como instâncias do 'juspositivismo', as tomam como sendo opostas, ou pelo menos claramente distintas, da teoria da lei natural" (FINNIS, 2007a, p. 83). Na ótica do professor de Oxford, os teóricos do
Direito natural, por sua vez, "não concebem suas teorias em oposição, ou mesmo em distinção ao juspositivismo" (FINNIS, 2007a, p. 83), aceitando perfeitamente que o Direito "pode ser considerado e denominado como, simultaneamente, um fato social puro de poder e prática, $e$ um conjunto de razões para a ação que podem ser e frequentemente são corretas como razões e, consequentemente, normativas para os povos razoáveis dirigidos por elas" (FINNIS, 2007a, p. 84).

Aliás, demonstrando nitidamente a influência aquiniana por ele recebida, Finnis assevera que teria sido Tomás de Aquino o responsável por primeiramente inserir a expressão "lei positiva" em maior circulação na Filosofia (FINNIS, 2007a, p. 83).

Este caráter duplo da lei positiva é pressuposto pela expressão bem conhecida de que "leis injustas não são leis". Entendida apropriadamente, esta expressão indica a razão "[...] da oposição positivista às teorias do direito natural ser inútil, isto é, redundante: o que os positivistas caracteristicamente veem como realidades a serem afirmadas é prontamente afirmado pela teoria da lei natural"; e o que eles caracteristicamente veem como ilusões a serem dissipadas não é parte da teoria da lei natural. (FINNIS, 2007a, p. 84).

De fato, o que Finnis pretende é demonstrar a relevância dos princípios inerentes à lei natural em relação à validade da lei elaborada a partir do exercício da atividade legislativa. Também é cediço dizer que a principal contribuição deixada por FINNIS quanto ao tema sobre o qual se discorre no presente texto reside em apontar e refutar a desarrazoada oposição endereçada à teoria do Direito Natural, frequentemente rotulada pela crítica positivista de ser obscura e supersticiosa. 


\section{CONCLUSÃO}

Malgrado o histórico embate entres as correntes positivistas e jusnaturalistas, e partir dos aportes teóricos buscados em Leo Strauss, Michel Villey e John M. Finnis, nota-se que o Juspositivismo e o Jusnaturalismo não são noções incompatíveis. Ao contrário, eles se complementam, cabendo ao Direito Natural o relevante papel de aferir o conteúdo moral do Direito Positivo, o que, para Finnis, alicerçado em Tomás de Aquino, opera-se por intermédio de um critério amparado na razoabilidade prática, sendo que o Direito, "ajustado para tomar um lugar diretivo no raciocínio prático que conduz ao julgamento moralmente adequado", existe em razão das pessoas humanas (FINNIS, 2007a, p. 101). Finnis demonstra claramente que o Direito configura uma instituição que precisa ser respeitada e obedecida, notadamente por se tratar de uma exigência razoável para a consecução da felicidade e paz social.

Assim, não obstante opiniões divergentes, as quais pugnam pelo enfraquecimento teórico do tema sob exame, o passar dos séculos, desde a Antiguidade
Clássica, transitando pela Idade Média e chegando até a quadra atual, demonstra justamente o contrário, posto não ter conseguido eliminar a estima dos pensadores pela temática desenvolvida no presente texto.

Os conflitos infanto-juvenis precisam ser geridos desde uma atuação conjunta entre setores sociais, setores públicos e privados. Essa defesa parte de um pressuposto de que o tratamento mais adequado dos impasses protagonizados por jovens pode ser resultado de investimentos em modelos restaurativos de prevenção, gestão e solução e não necessariamente remetidos ao Poder Judiciário como o grande repositório de demandas. e privados. A Justiça associada à assistência social, à educação e à saúde pode, por certo, ser essencialmente mais justa e transformadora.

O modelo de sociedade projetado pelo constitucionalismo democrático brasileiro, pós1988, não restringe ao Judiciário a solução de todas as adversidades. Pelo contrário, suscita a necessidade de cooperação do todo social para se consumar os preceitos básicos de unidade que assentam o Estado Democrático de Direito.

\section{REFERÊNCIAS}

ADEODATO, João Maurício. Ética e Retórica: para Uma Teoria Da Dogmática Jurídica, 5 ed. São Paulo: Saraiva, 2012.

ARISTÓTELES. Ética a Nicômaco. Brasília: UnB, 1997.

BARZOTTO, Luis Fernando. Filosofia do direito: os conceitos fundamentais e a tradição jusnaturalista. Porto Alegre: Livraria do Advogado Editora, 2010.

BITTAR, Eduardo C. B. Direito natural: sentido natural versus sentido cultural, Brasília, ano 38, ${ }^{\circ}$ 152, out./dez. 2001.

BITTAR, Eduardo C. B. O jusnaturalismo e a filosofia moderna dos direitos: reflexão sobre o cenário filosófico da formação dos direitos humanos, Panóptica, edição 13, 2008.

BITTAR, Eduardo C. B.; ALMEIDA, Guilherme A. de. Curso de filosofia do direito, 9 ed. São Paulo: Atlas, 2011. 
CASTILHO, Ricardo. Filosofia do Direito, 4 ed. São Paulo: Saraiva, 2017.

CUNHA, Mariana Palozzi Sérvulo da. O movimento da alma: a invenção por Agostinho do conceito de vontade. Porto Alegre: EDIPUCRS, 2001.

DINIZ, Maria Helena. Compêndio De Introdução Ao Estudo Do Direito, 12 ed. São Paulo: Saraiva, 2000.

FERRAZ JUNIOR, Tercio Sampaio. Introdução ao estudo do direito - técnica, decisão, dominação, 9 ed. São Paulo: Atlas, 2015.

FINNIS, John M. Direito natural em Tomás de Aquino: sua reinserção no contexto do juspositivismo analítico. Porto Alegre: Sergio Antonio Fabris Editora, 2007a.

FINNIS, John M. Lei natural e direitos naturais. São Leopoldo: Unisinos, 2007b.

MARCONDES, Danilo; STRUCHINER, Noel. Textos básicos de filosofia do direito: de Platão a Frederick Schauer. Rio de Janeiro: Zahar, 2015.

MARCONDES, Danilo; STRUCHINER, Noel. Textos básicos de ética - de Platão a Foucault. Rio de Janeiro: Zahar, 2007.

MONTORO, André Franco. Introdução à ciência do direito, 29 ed. São Paulo: Revista dos Tribunais, 2011.

MORRISON, Wayne. Filosofia Do Direito: dos Gregos Ao Pós-Modernismo, tradução de Jefferson Luiz Camargo. São Paulo: Martins Fontes, 2012.

NADER, Paulo. Introdução ao estudo do direito, 39 ed. Rio de Janeiro: Forense, 2017.

NADER, Paulo. Filosofia do Direito, 19 ed., São Paulo, Forense, 2010.

PINHEIRO, Victor Sales; SOUZA, Elden Borges. A Fundamentação ética dos direitos humanos em John Finnis. Revista Direitos Humanos e Democracia, Editora Unijuí, ano 4, n. 7, jan./jun. 2016, p. 65-83. Disponível em <file:///C:/Users/Cristiane/Downloads/5513-1-27093-1-10-20160805.pdf>. Acesso em: 16 jun. 2018.

REALE, Miguel. Lições preliminares de direito, 26 ed. São Paulo: Saraiva, 2002.

REALE, Miguel. Filosofia do direito, 19 ed. São Paulo: Saraiva, 2002.

SGARBI, Adrian. O direito natural revigorado de John Mitchell Finnis. Revista da Faculdade de Direito da Universidade de São Paulo, v. 102, p. 661-689, jan./dez. 2007. Disponível em: <http://www.revistas.usp.br/rfdusp/article/view/67774>. Acesso em: 20 jun. 2018.

SOARES, Ricardo M. F. Elementos de teoria geral do direito. São Paulo: Saraiva, 2013.

STRAUSS, Leo. Direito natural e história, 70. ed. Lisboa: Biblioteca de Teoria Política, 2009.

VILLEY, Michel. Questões de Tomás de Aquino sobre direito e política. São Paulo: Martins Fontes, 2014. 
WOLKMER, Antonio Carlos. Ideologia, estado e direito. São Paulo: Revista dos Tribunais, 1989.

Recebido em: 05/10/2017

Aceito em: 20/08/2018 
